OBETS. Revista de Ciencias Sociales

Vol. 10, n. ${ }^{\circ} 1,2015$, pp. 235-260

ISSN: 1989-1385

DOI: 10.14198/OBETS2015.10.1.09

\title{
CITIZEN PARTICIPATION IN EUROPE: A COMPARATIVE ANALYSIS FROM THE SOCIOPOLITICAL CONTEXTS ${ }^{1}$ \\ LA PARTICIPACIÓN CIUDADANA EN EUROPA: UN ANÁLISIS COMPARADO DESDE LOS CONTEXTOS SOCIOPOLÍTICOS
}

\author{
Ernesto Ganuza Fernández \\ Institute for Advanced Social Studies - Spanish Research Council, Spain \\ eganuza@iesa.csic.es \\ Francisco José Francés García \\ Department of Sociology II. University of Alicante, Spain \\ francisco.frances@ua.es
}

\begin{abstract}
Questioning the social spiral deriving from participation has flared up the debate regarding the place it occupies in contemporary democracies. It does not seem possible to deny the evidence that many studies have pointed to regarding the political attitudes associated with institutionalised participation (associations). But we question in this study the fact that the whole participation phenomenon is equated with that type of participation. Our paper compares different ways of participation in a sample of European countries to, first, analyse the activities that can be linked to each form of participation and whether it can be held that they are different from the point of view of the individual. Second, we analyse the attitudes that lead individuals to choose one option over the other. We conclude that for individuals the different forms of participation are different forms of political engagement. Our study shows an evolution in non-institutional forms of participation over time that is difficult to ignore, from being expressions bordering illegality to taking them as
\end{abstract}

\footnotetext{
${ }^{1}$ This work was supported by the Spanish Ministry of Science and Innovation under Grant number CSO2012-38942
} 
normalised tools for citizens. We could now start to consider them from the point of view of the implications they have for democracy as a different way to exercise political influence.

Key words: social capital; new ways of participation; political engagement; protest; democracy

\section{Resumen}

El cuestionamiento de la espiral social derivada de la participación ha intensificado el debate sobre el lugar que ocupa este fenómeno en las democracias contemporáneas. No es posible negar la evidencia que muchos estudios han señalado acerca de la importancia de las actitudes políticas asociadas a la participación institucionalizada. Pero en este estudio nos preguntamos si todo el fenómeno de la participación se equipara con ese tipo de participación. En nuestro trabajo se comparan diferentes formas de participación con una lógica comparativa en una muestra de países europeos con un doble objetivo. En primer lugar, analizar las actividades que se pueden vincular a cada forma de participación y si se puede considerar que son diferentes desde el punto de vista de los sujetos. En segundo lugar, analizar las actitudes que llevan a las personas a elegir una opción sobre la otra. Las conclusiones muestran que para las personas las diferentes formas de participación suponen diferentes formas de compromiso político. En los resultados se observa una tendencia hacia formas no institucionalizadas de participación que es difícil de ignorar, hasta el punto que han terminado por convertirse en herramientas normalizadas para los ciudadanos, por lo que conviene considerarlas desde el punto de vista de las consecuencias que tienen para la democracia como una forma diferente de ejercer influencia política.

Palabras clave: capital social; nuevas formas de participación; compromiso político; protesta; democracia

\section{INTRODUCTION}

When we think of citizen participation we often think of the quality of democracy: the higher the number of citizens who participate, the better the democratic institutions one might expect (Uslaner and Dekker 2001). Participation has a positive systemic effect on society as a whole (Putnam 1993). The decline in participation is interpreted as citizens' indifference, which from the point of view of political theory implies poorer governance (Offe, 2006).

This Neo-Tocquevillian thesis is widespread and dominates not only the academic landscape, but also the administrative landscape in the form of guidelines from international bodies for local and regional administrations to improve the quality of democratic institutions (OECD 2001). Moreover, the systemic effect of participation on society is normally identified with associative participation, which, for many, represents the very core of democratic participation, given that it is through these ways of participation that the attitudes conducive 
to a vigorous democracy materialise (Putnam 1993; Warren 2001; Hirst 2002). Associative participation is capable of generating democratic habits and attitudes among individuals, such as awakening an interest in those who think differently, in addition to making it easier for people to put themselves in the shoes of others or to learn to debate in a non-coercive setting.

This thesis has been questioned by empirical studies on both sides of the Atlantic. The theses of Mutz (2006) and Theiss-Morse and Hibbing (2005) have openly questioned the capacity of associations to generate democratic behaviour. Members of organisations, according to these studies, are not the most open or the most politically socialised citizens. Along these lines, in the US it has been suggested that the capacity of associations to remove citizens from politics may even be greater than their capacity to include them in politics (Eliashop 2001). In Europe we find similar arguments, albeit more moderate in their conclusions (Meer and Ingen 2009; Newton 2007). The main criticisms question the positive effects of associationalism. For many, it would be necessary to take into account the type of association (Deth 2001; Wollebaeck and Selle 2002), whether they are actually representative (Eliasoph 2001; Deth 2006) or whether we can actually expect them to generate social capital (Newton and Norris 2000, Uslaner and Conley 2003; Newton 2006; Lichterman 2006). Associations are also starting to be questioned as schools of democracy. Meer and Ingen (2009) suggest that it would be more accurate to speak of associations as pools of democracy, that is, as receivers of people who already have those qualities and practice them, rather than as places where people learn the civic values that supposedly go with the exercise of democracy.

The criticisms have not stopped at associations. Some academics believe that if civic behaviour can no longer be expected from associations, perhaps the time has come to stop insisting on citizen participation as a central element of contemporary democracies. The subtitle of Mutz's book in the US, opposing deliberation and participation, is illustrative (Mutz 2006). Although not conclusive, her work leaves open a question of undoubted importance for the development of democracy based on deliberative principles. Those of whom one could expect an acceptance of these principles (those engaging in participation) actually oppose them, so the question arises as to whether deliberation might not be a chimera.

This paper takes this question as a starting point, together with the question as to whether we can indeed assume that participation in general has none of the qualities that have always been associated with it. We suggest distinguishing between conventional and non-conventional participation, and analysing them as two different models of political engagement. The normalisation of non-con- 
ventional forms of participation has been a subject of research for some years now (Norris et al. 2006; Dalton 1999). Our question would be, then, whether what is normally understood as participation (in associations) might also form part of non-conventional forms of participation. Are people who participate in associations really more committed to society? Are they more open, tolerant or sociable? To what extent are both forms of participation equivalent in terms of promoting democratic attitudes?

Our paper compares both forms of participation in a sample of European countries. Our goal is, first, to analyse the activities that can be linked to each form of participation and whether it can be held that both forms are different from the point of view of the individual. Second, we analyse the attitudes that lead individuals to choose one option over the other. Thus, we hope to answer the question as to whether all forms of participation are equivalent with regard to the social spiral that is expected from the political engagement of individuals, which we believe will allow us to gain a better understanding of the phenomenon of participation.

\section{INSTITUTIONAL AND NON-INSTITUTIONAL WAYS OF PARTICIPATION}

We owe Barnes and Kaase (1979) the conceptual distinction between conventional and non-conventional participation. This distinction, however, rests on conventionality criteria, that transmit a strong contrast between forms of participation deemed to be 'normal' and others that were not deemed so at the end of the seventies. This led to non-conventional forms being identified as forms on the fringes of legality. At the time, some important studies projected socio-political disasters based on the evolution of non-conventional participation (Crozier et al. 1975). Today, however, that position is no longer tenable.

The social changes of recent years have led to non-conventional channels becoming normal political expressions (Michelletti et al. 2004; Norris 2006). The profile of participants is no longer minority groups (Aelst and Walgrave 2001) and the new social movements use non-conventional channels all the time (Porta and Diani 1999). All this suggests that it may be useful to revisit the classical distinction made by Barnes and Kaase. If, instead of using a criterion such as conventionality, which is liable to change over time, we apply an organisational criterion, from the individual point of view it would be better to speak of institutional and non-institutional forms of participation. This has been addressed by different studies, although it has yet to be addressed systematically (Offe 1985; Porta and Diani 1999). This change would help us translate the different costs of participation for individuals, in addition to taking into account the different purposes of participative action. It is not the same to participate through an association as it is to attend a demonstration. The former 
requires an organisational structure where the individual has to participate through an administrative body, whether it is an organisation (voluntary, political, trade union, etc.) or whether it is through a contact with the administration. The latter, however, does not require prior organisation on the part of the individual and can be an occasional affair (donating funds, demonstrating, boycotting products on the market, etc.), conferring this form of participation, from the individual point of view, a self-organisational nature, which is absent in the former type of participation.

Following the Neo-Tocquevillian theses, through non-institutional participation we might expect a smaller social spiral than through institutional participation, to the extent that direct contact among participants is not required and is not necessary to sign a petition or engage in an act of consumerism, for instance. However, the results of the research made provide evidence that allow us to question this axiom. For instance, the research on the way in which associations organise themselves have shown that they tend to adopt a hierarchical structure, adopting a corporate way of operating in the defence of a set of interests, which makes it difficult even to speak of politics (Maloney and RoBteutscher 2007; Eliashop 2001). How that defence takes place and how that negotiating position is built poses a dilemma within the literature of social movements. Some consider that this corporate structuring, following Michels' iron law of oligarchy, implies the success of the association (Gamson 1990), which would imply the professionalization of protest and a legitimation of the passive role of its members (Jordan and Maloney 1997). Others consider it to be a failure and that new social movements are precisely an alternative to this trend, in that the necessary corporatisation of the group does not occur at the expense of reducing membership to a passive role (Cohen and Arato 1992: 442). One of the characteristic elements of the new social movements is the use of non-institutionalised formal channels as a means of political expression. The dilemma lies in the ability to preserve internally democratic decision-making models and broad debates regarding the goals of the association. This dilemma is central to our problem, as it is exactly what supports (or fails to support) the projection of the value of generating civic habits on to associations, as contact with other interests and the search of agreement is meant to have a positive effect on its members and facilitate the development of the social spiral. Having said that, this could only happen if the members participate actively in the process.

Recent research on participation has pointed out that the different civic skills of citizens, however, are a result of them belonging or not to an association, to a greater extent than of them having a more or less active role within them (Meer and Ingen 2009). This would be the equivalent of saying that asso- 
ciations and their way of operating do not generate differences among their members and, therefore, that them having hierarchical structures are not important. If this is so, neither should we expect great differences between the civic skills of individuals who decide to participate through institutional and noninstitutional forms of participation, given that, after all, the participatory mechanisms would select citizens who were already socialised in the civic values of democracy.

Our goal is to test this hypothesis in order to evaluate to what extent these two forms of participation are the same from the point of view of the individual. The relationship between both forms of participation has yet to be explored in detail. Most studies have focused on the representativity of participants in one way or another (Norris et. al. 2006; Jan van Deth 2006) and, especially, on the relationship between democratic attitudes, such as social trust and institutional trust, and institutional forms of participation (Norris 2001; Newton 2006; Torcal and Montero 2006). This has raised doubts as to the civic effects of associationalism (Norris 2001; Eliasoph 2001; Wollebaek and Selle 2002; Kwon 2004; Lichterman 2006; Newton 2006). Although not all research raises this doubt regarding democracy and associationalism (Putnam 2000; Hirst 2002; Kwak et al. 2004), the question remains. The fact that we think of social trust in relation to activities usually thought of as associational is deeply rooted in contemporary democracies, and specifically in the public models of participation encouraged by the different administrations (OECD 2001; Wollmann 2003). However, several authors argue that trust in people should be positively associated with non-conventional activity, as the ability to trust others is the factor which would, ultimately, reduce the perceived costs of being non-institutional. As Uslaner showed, in many countries, social trust trends are not related with patterns of conventional political participation (Uslaner 2004). The work of Eliasoph and Lichterman in the U.S. also questions the ability of institutional forms of participation to generate civic values traditionally linked to them (Eliasoph 2001; Lichterman 2006). In Europe, Deth (2006) comes to accept this view in a study on participation in Europe.

The research for this paper was carried out on data for four European countries, allowing us to analyse the phenomenon from four democratic contexts with differing characteristics: France, Spain, Germany and Norway. All these countries have established democracies, but with differing levels of development and different ways of operating. France and Germany are each examples of central and federal governments. Germany and Norway have administrations where the municipalities manage a high percentage of public expenditure. If we have into account the presence of public workers in the different administrative levels, we'll see that $60 \%$ of Norway's public workers are in local level, while they 
Figure 1. Explanatory order of the variables proposed

\begin{tabular}{|c|}
$\begin{array}{c}\text { Independent variables } \\
\text { (exogenous) } \\
\text { Associational activity } \\
\text { Closeness to a political party } \\
\text { Ideological self-placement } \\
\text { Social trust } \\
\text { Trust in institutions } \\
\text { Trust in politicians } \\
\text { Talk about politics } \\
\text { Access to political information through the } \\
\text { media } \\
\text { Understanding of political sphere } \\
\text { Interest in politics } \\
\text { Sociability }\end{array}$ \\
(endogenous)
\end{tabular}

are 30\% in Germany and around 22\% in France and Spain. In France, more than $50 \%$ of public workers are in state level, while in Spain are 23\%, in Norway hardly $19 \%$ and in Germany around 12\% $\%^{2}$. This distribution shows the importance of administrative issues at local, regional or state level. The issues managed at local level in north countries are quite more important than in south countries. If we think the traditional link between local issues and participation, we could expect more participation in north countries as literature nevertheless has already showed ${ }^{3}$. Spain is a relatively new democracy compared to the other three countries. Anyway, in all four countries, noninstitutional forms of participation cannot be considered to be strange forms of participation, which is necessary if we want to look at the interrelation of both forms of participation (see Table 1). Our aim is, first, to analyse the extent to which the values traditionally associated with civic democracy are linked to

${ }^{2}$ The data come from Spain (Ministerio de Administraciones Públicas, 2008); France (Direction Générale de l'Administration et de la Fonction Publique and Ministere de la Fonction Publique et de la Reforme de l'Etat, 2008); Germany (Federal Statistics Office, 2008); Norway (Statistics Norway, 2008). All data can be consulted online.

${ }^{3}$ A very good research about associations in Europe, providing a general view of differences and structures among countries in Europe would be Maloney and RoBteutscher, Social capital and associations in European democracies: a comparative analysis. 
the two forms of participation, with both forms cohabiting in the public sphere, and, second, to look at the differences between the four countries.

We start by proposing an explanatory model of individual participation through institutional and non-institutional channels, which we shall evaluate in each of the four countries. These variables are the dependent variables, which we shall attempt to explain based on the attitudinal variables normally included in studies on participation. Figure 1 shows a general chart of our theoretical proposal.

\section{METHODOLOGY AND ANALYSIS}

A comparative analysis of European countries requires a uniform and complete database in order to achieve a correct empirical explanation. This requirement is met in the European Social Survey (ESS), which for this purpose offers high standards of data. As a determinant factor, only the first round of this survey, developed in 2002 and 2003 fulfills the necessary requirements to have a sufficient number of variables allowing to develop an analysis on participation in depth. In any case, the analysis discussed in this article presents schemes that define contexts of participation linked to models of democracy with structural nature essentially stable in time in the countries studied, what gives validity and consistency to managed data.

The analysis has been carried out using SEM (Structural Equation Modeling), possibly the multivariate statistical technique best suited to studying and analysing multiple dependence relationships established between the variables that form part of a social process. One of the main advantages of using this technique is the possibility of analysing multiple relationships between subsets of variables. The goal is to place on the same analytical plane the different variables linked to the two forms of participation we propose to study. The study of the possible variations in the resulting structures of the four countries analysed should allow us to appreciate the differences in the act of participation, not through an observation of each separate dimension, but integrating the different dimensions that make up the behaviour of subjects.

The design strategy for the models was as follows: First, the latent variables were built into the model based on the indicator variables contained in the ESS questionnaire. We have chosen to include as indicator variables of the forms of participation those activities most common in the countries included in the study (table 1), leaving out of the analysis other indicator variables included in the ESS such as taking part in illegal protests, donating funds to groups or belonging to a political party, due to their marginal frequencies and low variability for analysis. 
Table 1: Percentage of individuals who have carried out the following actions in the last 12 months in countries studied

\begin{tabular}{|c|c|c|c|c|c|c|}
\hline & & Spain & France & Germany & Norway & Cumulative \\
\hline \multirow{3}{*}{ 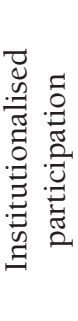 } & $\begin{array}{l}\text { Contacting a politician } \\
\text { or official of the } \\
\text { Administration }\end{array}$ & $11.7 \%$ & $16.8 \%$ & $13.0 \%$ & $23.9 \%$ & $16.1 \%$ \\
\hline & $\begin{array}{l}\text { Collaborating with } \\
\text { citizen organisations }\end{array}$ & $14.6 \%$ & $17.0 \%$ & $18.2 \%$ & $28.1 \%$ & $19.7 \%$ \\
\hline & $\begin{array}{l}\text { Collaborating with a } \\
\text { political party }\end{array}$ & $5.8 \%$ & $4.5 \%$ & $3.8 \%$ & $9.4 \%$ & $5.8 \%$ \\
\hline \multirow{6}{*}{ 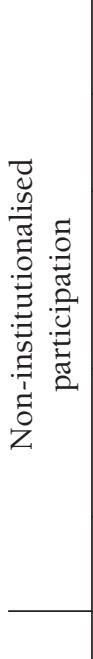 } & $\begin{array}{l}\text { Signing petitions in } \\
\text { campaigns }\end{array}$ & $22.3 \%$ & $33.8 \%$ & $31.3 \%$ & $37.1 \%$ & $31.3 \%$ \\
\hline & $\begin{array}{l}\text { Taking part in } \\
\text { demonstrations }\end{array}$ & $16.1 \%$ & $16.9 \%$ & $11.4 \%$ & $9.0 \%$ & $12.8 \%$ \\
\hline & $\begin{array}{l}\text { Boycotting or not } \\
\text { buying products for } \\
\text { political or ethical } \\
\text { reasons }\end{array}$ & $7.7 \%$ & $25.8 \%$ & $24.6 \%$ & $20.2 \%$ & $20.2 \%$ \\
\hline & $\begin{array}{l}\text { Donating funds to a } \\
\text { political organisation } \\
\text { or group }\end{array}$ & $4.8 \%$ & $3.3 \%$ & $9.3 \%$ & $11.6 \%$ & $7.8 \%$ \\
\hline & $\begin{array}{l}\text { Taking part in illegal } \\
\text { protests }\end{array}$ & $1.7 \%$ & $2.3 \%$ & $1.3 \%$ & $0.8 \%$ & $1.4 \%$ \\
\hline & $\mathrm{N}=$ & 1.728 & 1.503 & 2.919 & 2.036 & 8.186 \\
\hline
\end{tabular}

Source. ESS (Round 1)

Tested together in the statistical model created, the five activities considered allow us to evaluate the two forms of social and political participation under study as differentiated phenomena, representing two latent (endogenous) variables, for which we will then explore explanatory relationships on the basis of attitudes towards participative action.

Second, based on the exogenous variables that make up the participatory attitudinal context, explanatory models of the forms of participation for the four countries have been proposed, based on working hypotheses. We identified the underlying structure in the data and subsequently adjusted the models. The resulting models show empirically significant explanatory relationships among the variables at play. In this regard, it was not suitable to undertake a multigroup 
analysis, given that the exogenous variables that form part of the structure in each model may vary depending on the country and on the empirical fit of these variables. The goal was to check the variance or invariance of the structures between the different countries and the possible changes in the coefficients of relationships between the variables. This allows us to observe how the nature of the exogenous variables and explanatory loads changes in the different models depending on the participation scenarios of each country, and how the coefficient values gain weight in some cases and decrease in others. The result is the identification and testing of the four models presented below.

\section{Figure 2. Spain's Model}

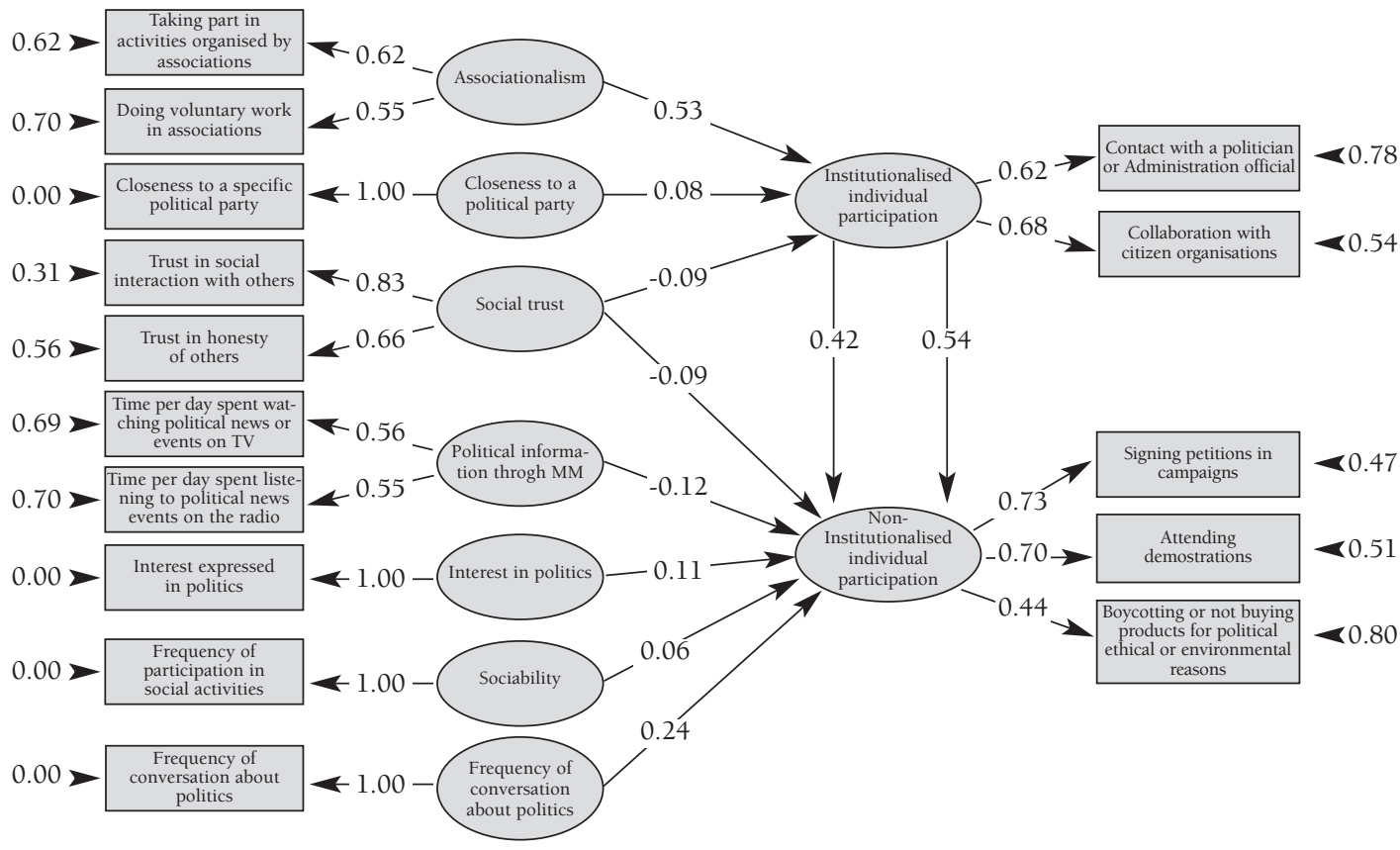




\section{Figure 3. France's Model}

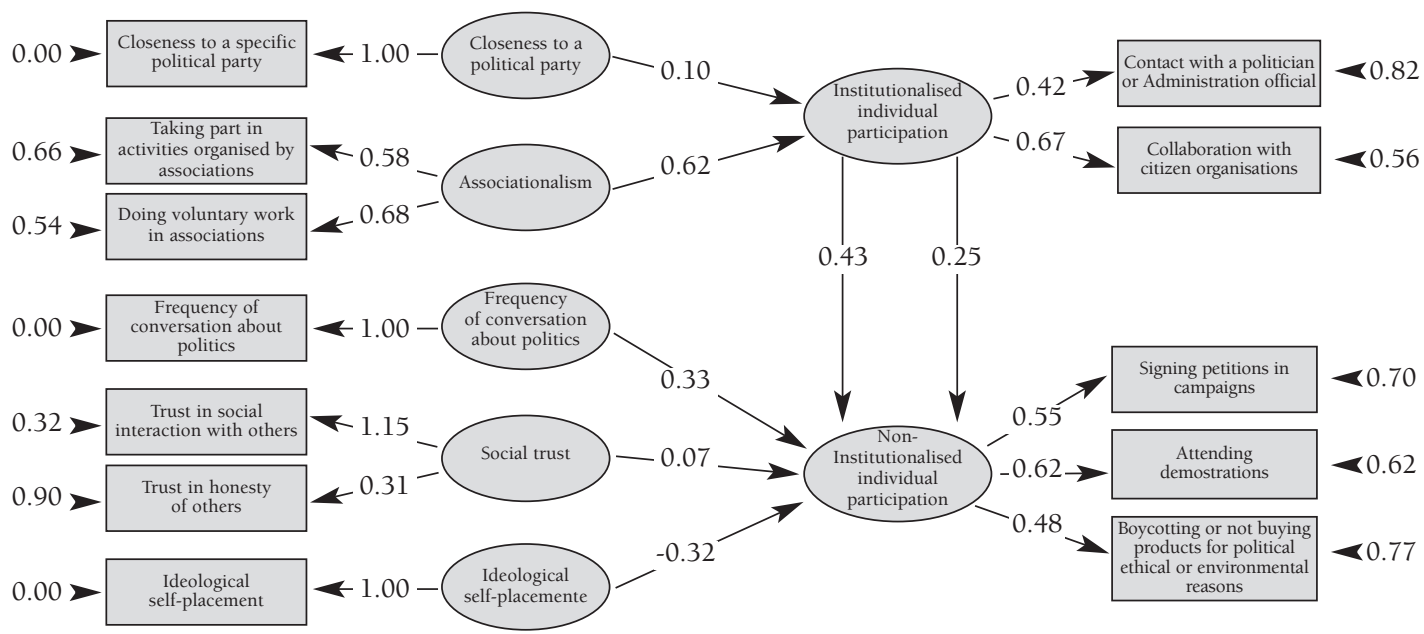

Figure 4. Germany's Model

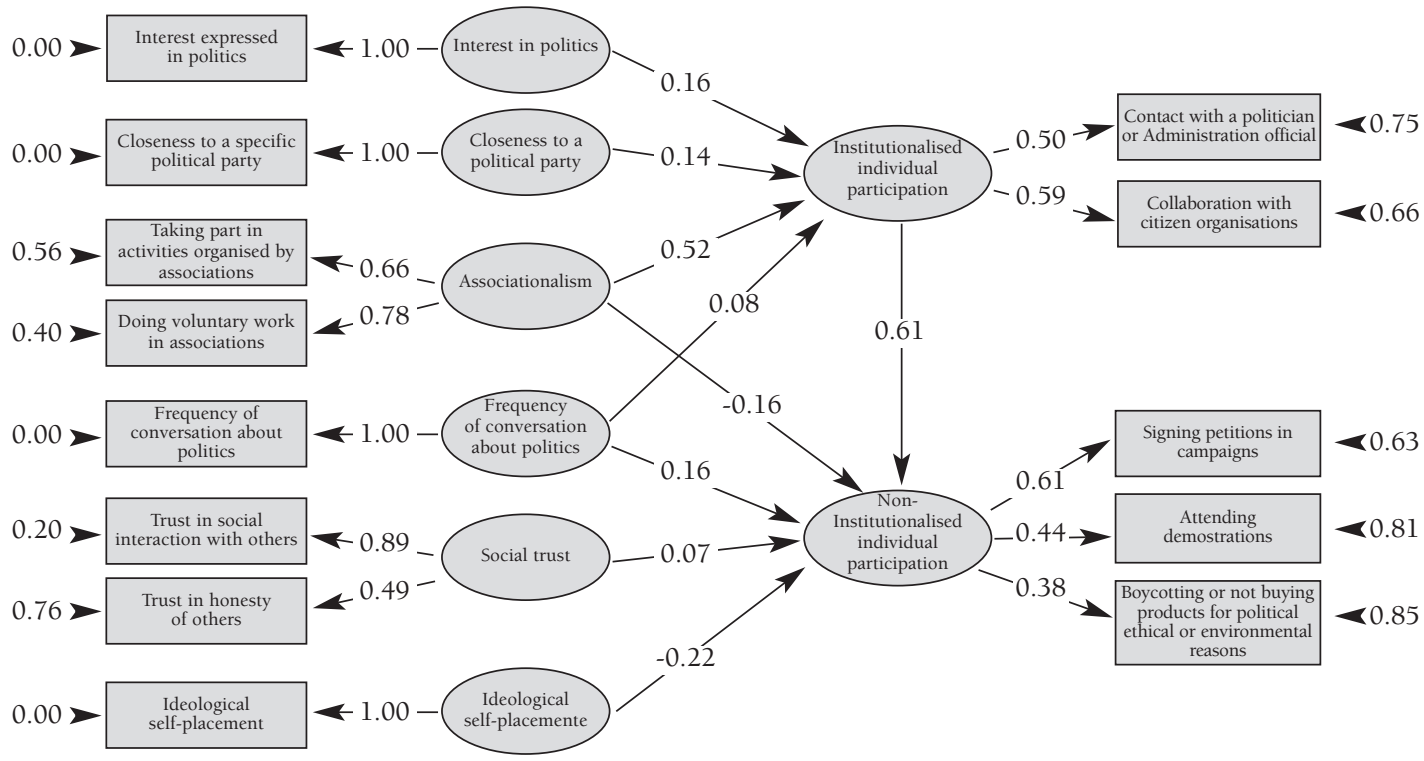




\section{Figure 5. Norway's Model}

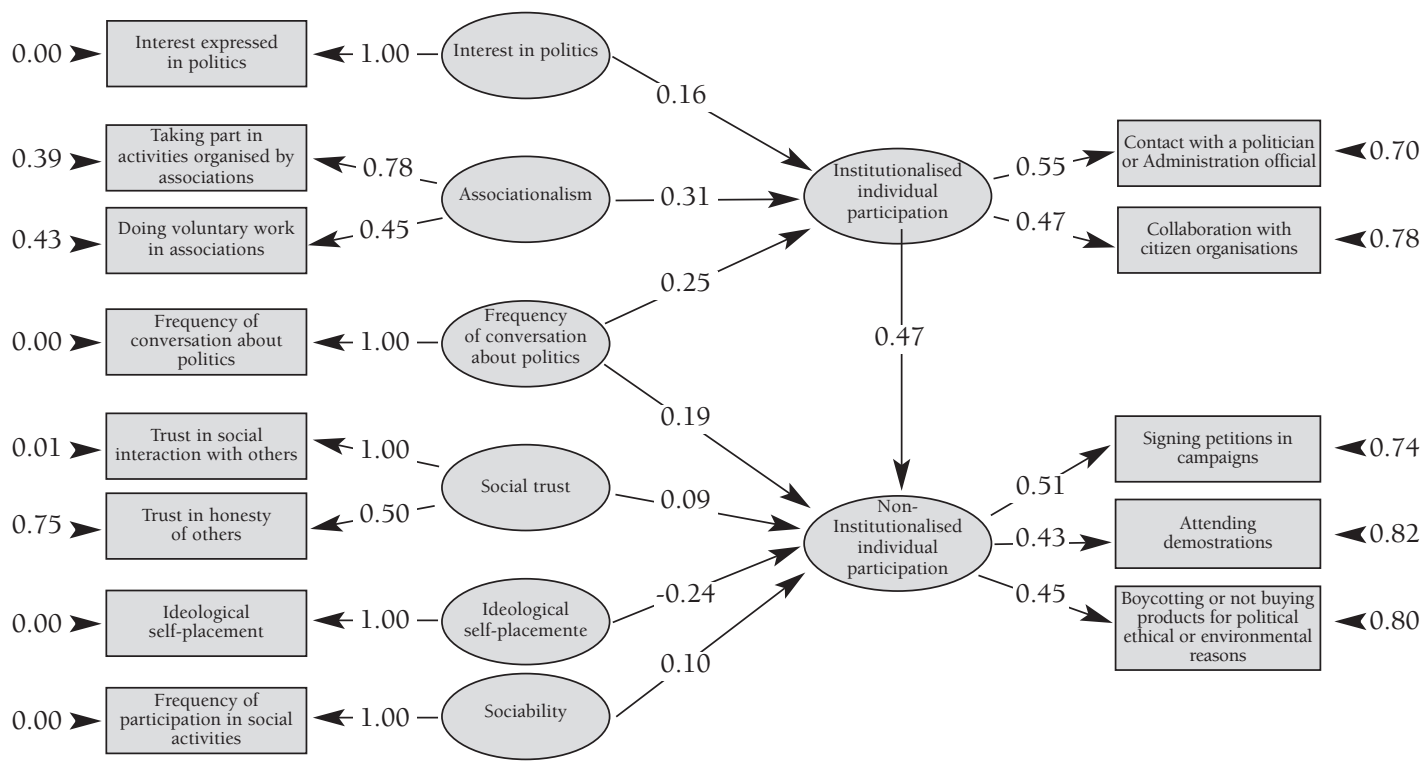

\section{EMPIRICAL FIT OF MODELS}

Goodness of fit tests determine whether the models that are being tested are acceptable. Three sources are normally used to assess the models. In this paper we present two of them. The first is the assessment of the global indices of goodness of fit. The second, the consideration of the significance of the relation coefficients between the variables in the diagrams of the models. These coefficients will help us evaluate graphically the relations of dependence between the variables that make up the models. The diagrams only show empirically significant coefficients. We have left out the third source of assessment, the presentation of structural equations, because, not being directly relevant for the hypotheses put forward, they may hinder the presentation of the argument.

Jöreskog and Sörbom (1989), developers of the Lisrel program, recommend the use of two goodness of fit indices: GFI (Goodness of Fit Index) and AGFI (Adjusted Goodness of Fit Index). Rex Kline (1998) also recommends taking into account the results of a further three statistical tests: NFI (Normed Fit Index), NNFI (Non Normed Fit Index) and SRMR (Standardized Root Mean Square Residual). The following table shows the results of all these indices for the four models proposed. 
Table 2. Goodness of fit coefficients of the models

\begin{tabular}{c|c|c|c|c|c|c}
\hline $\begin{array}{c}\text { Statistical } \\
\text { tests }\end{array}$ & Variation & $\begin{array}{c}\text { Recommended } \\
\text { values }\end{array}$ & $\begin{array}{c}\text { Spain's } \\
\text { Model }\end{array}$ & $\begin{array}{c}\text { France's } \\
\text { Model }\end{array}$ & $\begin{array}{c}\text { Germany's } \\
\text { Model }\end{array}$ & $\begin{array}{c}\text { Norway's } \\
\text { Model }\end{array}$ \\
\hline RMSEA & $<0.05$ & 0.009 & 0.031 & 0.019 & 0.023 \\
\hline GFI & $0-1$ & $>0.90$ & 0.99 & 0.99 & 0.99 & 0.99 \\
\hline AGFI & $0-1$ & $>0.90$ & 0.98 & 0.98 & 0.99 & 0.98 \\
\hline NFI & $0-1$ & $>0.80$ & 0.98 & 0.96 & 0.98 & 0.98 \\
\hline NNFI & $0-1$ & $>0.95$ & 1.00 & 0.97 & 0.99 & 0.98 \\
\hline SRMR & & Close to 0 & 0.017 & 0.026 & 0.019 & 0.021 \\
\hline
\end{tabular}

Source: Own elaboration

As shown in the table, the fit indices have values within the ranges considered acceptable. The fit tests show very low RMSEA coefficients (below 0.05 in the four cases), as well as values above the minimum recommended values in all goodness of fit tests, which tells us that the models we propose fit adequately with the data and are adequate for capturing the reality under study.

\section{RESULTS AND DISCUSSION}

Diagrams can be very useful to describe and assess the relations of dependence established between the variables. In the diagram we present, which is offered in its standardised solution (figures 2 to 5), we can distinguish between the structural model (comprised of the latent variables and their relations) and the measurement models (the systems of indicator variables for each of the latent variables). The measurement models regarding the latent variables still show an adequate empirical fit, maintaining at large a relevant explanatory load with regard to the indicator variables, and therefore expressing an adequate measurement of the latent variables that generate them. We will not describe the measurements obtained, given that they confirm the same empirical fit as that obtained previously. This allows us to focus on the general results of the model, that is, on the relations between the latent variables. In order to facilitate and add to the reading of the comparative results between the structures of the countries included in the study, we show the matrix of the effects among the variables analysed with the $t$ values present in the relations of the models (table 3 ). 
Table 3. Matrix of effects and t values for the models of each country

\begin{tabular}{l|c|c|c|c|c|c|c|c}
\hline & \multicolumn{2}{|c|}{ Spain } & \multicolumn{2}{c|}{ France } & \multicolumn{2}{c|}{ Germany } & \multicolumn{2}{c}{ Norway } \\
\hline & PI & PNI & PI & PNI & PI & PNI & PI & PNI \\
\hline Associationalism & 7.79 & & 8.31 & & 12.26 & -2.75 & 6.48 & \\
\hline Closeness to a political party & 2.27 & & 2.70 & & 4.75 & & & \\
\hline Social trust & -1.96 & 3.86 & & 1.97 & & 2.09 & & 2.41 \\
\hline Political information through MM & & -2.80 & & & & & & \\
\hline Interest in politics & & 3.33 & & & 5.01 & & 5.40 & \\
\hline Sociability & & 2.11 & & & & & & 2.87 \\
\hline Frequency of political conversation & & 6.56 & & 8.06 & 2.40 & 4.87 & 5.87 & 4.13 \\
\hline Ideological self-placement & & & & -8.38 & & -7.69 & & -6.73 \\
\hline Institutionalised participation & & 6.16 & & 6.25 & & 7.81 & & 6.19 \\
\hline Non-institutionalised participation & 6.04 & & 3.27 & & & & & \\
\hline
\end{tabular}

* PI=Institutionalised participation PNI= Non-institutionalised participation

The first result shows us that in Spain and France we find a reciprocal relationship between the endogenous variables, that is, between the institutional and non-institutional forms of participation; whereas in Norway and Germany this reciprocity does not hold. This shows us that both forms are, from the point of view of individuals, complementary in the two Southern European countries, whereas they are not so in the other two. In addition, in the two Northern European countries the relationship is a one-way relationship, with institutionalised participation having a significant influence on non-institutional forms of participation but not vice-versa. This could suggest a break between both forms of participation, especially as regards those who participate in non-institutionalised ways, who do not seem to find in the other forms an adequate channel for political expression. In Germany that break is perhaps even clearer if we observe that, furthermore, participating actively in associations is negatively related with non-institutionalised forms of participation.

If we consider the relationship of the forms of participation with political attitudes, we can distinguish two different profiles in the four different countries. Institutional forms of participation are positively related with associationalism and closeness to a political party. This means that an individual who participates actively in an association or feels close to a party is more likely to participate through institutionalised ways in the four countries analysed. The only 
exception to this argument is Norway, where closeness to a political party is not related with any of the forms of participation. However, an individual's interest in politics does have a positive relationship with institutionalised participation in Norway and also in Germany. This nexus confirms much of the research carried out regarding the influence of political interest on participation in associations (Deth y Elf 2004). However, this relationship does not only fail to hold true in the other countries, but it is actually the other way around there, as the interest-in-politics variable in Spain has a positive relationship of influence with non-institutionalised forms of participation.

Non-institutionalised forms of participation, on the other hand, are positively related with the trust of individuals in society and the frequency with which they talk about politics in the four countries. This means that if there is an increase in the level of trust in society where individuals live, there is an increase in likelihood of participating through channels outside the institutional framework designed to participate, as pointed out by Uslaner (2004). This is a shift from the explanations of participation, especially if we take into account that speaking about politics also increases the likelihood of engaging in noninstitutional participation, even though in Germany and Norway that variable influences both forms of participation alike. However, the attitudinal distinction between one form of participation and the other is reinforced in general terms if we observe that sociability has a positive influence on non-institutional participation in Spain and in Norway, which can allow us to talk of two models of participation with different attitudinal relationships in all countries.

Having said that, although we can generally talk of two different attitudinal models of participation, we also find differences between the models of participation in the four countries. This means that although non-institutional participation could be understood as an option for the most open individuals, who speak about politics most often or who are more sociable, the further North we go, the more attention the institutional model of participation garners from those individuals who express concern about politics or awareness of what is happening around them, whereas the further South we go, the situation is the other way around, that is, an interest in politics or an awareness of what is happening around them, according to the definition of Deth and Elff (2004), are more likely to increase the chances of engaging in non-institutional participation. This suggests to us the existence of a greater distance between institutional politics and citizens in the South.

The relationship is not easy, but makes sense if we observe that in Germany and in Norway we can point to a certain degree of distancing between the two models of participation. In both countries, non-institutional participation is 
ideologically biased, that is the more progressive an individual is, the more inclined they will be to participate in these ways. If we consider that both forms of participation are not complementary, that leaves non-institutionalised forms as a more biased channel of participation than in France and Spain, where the reciprocity of both models makes the forms of participation more of a repertoire available to individuals than a form of identity. In addition, the fact that being active in associations has a negative relation with non-institutional participation in Germany, isolates this form of participation even more. The difference is clear in the case of France, where as in Germany and Norway, ideology has an influence on non-institutionalised ways of participation. However, in France both forms are complementary, which reduces the general weight of the ideological bias, given that through the institutional forms there is also participation in the other repertoire of participation activities.

We might think that the differences in the participation models among the countries might be due to the fact that non-institutionalised forms of participation are not yet widespread in the two countries furthest North, but in fact if we look at the frequency of the different participation actions (Table 1), except for demonstrations, that are more frequent in France and Spain, the other activities are even more common in Germany and Norway. Another explanation could be the influence of political structure on the opportunities to participate (Political Opportunity Structure), as it is true that municipalities in Germany and Norway manage a significantly higher part of public resources than those in France and Spain, which could enable access to institutional politics ${ }^{4}$. Before attempting to provide a reasonable explanation of those differences, what we can ascertain is that the political participation models have different attitudinal relationships with individuals, so from the point of view of the participants, one model does not seem to be the same as the other, despite the fact that in Norway and Germany the institutional model is slightly different to that in France and Spain.

\section{CONCLUSION}

Having seen the relationships that emerge from the models, tested their empirical validity and described the statistical coordination between the causal

\footnotetext{
${ }^{4}$ It's well known that citizens participate more when they can influence political issues. Bryan in his research Real Democracy: The New England Town Meeting and How It Works has showed how in Town Meetings the participation increases when school issues are at stake. Schlozman, Verba and Brady showed the relevance of this problem in the phenomenon of participation, 'Participation's not a paradox: the view from American activists'.
} 
mechanisms, we are now in a position to attempt to understand some of the issues which arise regarding participation in the four countries analysed, exercising the caution required when using these tools.

Institutional and non-institutional forms of participation have often been put forth as complementary forms of participation (Barnes and Kaase, 1979; Offe, 1985; Torcal and Lago, 2006). According to the result of our model we should qualify the sense of this complementariness, as it is true that it always goes in one direction, from the point of view of institutional participants, but it does not always hold in the opposite direction. This shows 1) that there are citizens who only participate through non-institutional forms and 2) that both forms of participation have a different sense from the point of view of the participants.

If this were true, we might think that it is not the same to take part in one form or the other from the point of view of the individual and, therefore, that the participatory phenomenon cannot be understood solely from the point of view of associations. In this context, the question arises as to why in France and Spain there is a higher degree of complementariness between the different forms of participation. In the sample of countries selected, this complementariness shows a reverse logic to that of formal participation, as the country with the lowest associational intensity (Spain) offers the highest degree of complementariness (Table 1). In addition, in Spain, the use of non-institutional forms of participation is more evenly distributed across the population, it being the only country where this participation does not have an ideological bias. On the other hand, Norway has the highest level of associationalism, together with Germany (Table 1) and, however, these are the two countries where the forms of participation are not complementary.

The fact that that in France both forms of participation are complementary, even though non-institutional forms have a stronger ideological bias, suggest that the problem is not so much democratic longevity, which we could associate with Spain. It would seem more reasonable to think of the differences in participation among the countries in terms of the characteristics of the institutional designs or the Political Opportunity Structure. This concept was first developed in the research on social movements and it tried to take into account the 'specific configurations of resources, institutional arrangements and historical precedents for social mobilization, which facilitate the development of protest movements in some instances and constrain them in others' (Kitschelt 1986 -as quoted in Arzheimer and Carter 2006-). Political opportunity structures showed the relevance of exogenous conditions for organization success, in 
contrast with actor-centred theories (Tarrow 1998) ${ }^{5}$. If we take into account that institutional participation takes place mainly at the municipal level (both associative and when it comes to contacting officials), one would expect the former to be sensitive to local administrative dynamics. In this regard, the management capacity of municipalities in Germany and Norway is significantly higher than that of municipalities in France and Spain, as they have more resources under their direct management. In Spain, most public management (education, health, social services) is carried out by regional administrations (in France, the state administration) and not by municipalities (Chandler 2000), which may distance citizens from the political arena, favouring a non-institutional form of political influence. This is unlike what happens in the two countries furthest to the North, where the higher rate of institutionalised participation could offer citizens a more credible means of influence to solve the problems that affect them. In this regard, it is telling that citizens with an interest in politics and who talk about it with friends are more inclined to participate through non-institutional channels rather than institutional channels in France and Spain. Whereas in Germany and Norway, the case is the opposite: those with an interest in politics and who talk about it with friends tend to engage in institutional participation.

The importance of institutional design (POS) may provide a reasonable explanation of the differences found between the participation models in the four countries, especially with regard to interest in politics of individuals and the complementariness or not of the forms of participation. From this point of view, non-institutional channels seem to offer citizens in France and Spain a better or more useful way of influencing decision-making processes. However, this hypothesis does not help us understand the attitudinal differences we find associated to each of the two forms of participation, given that in the four countries of the sample, non-institutionalised participation is associated with an individual with social trust and who talks with his friends about politics, even in Germany and Norway, whereas institutional participation is always linked with closeness to a political party or to the level of associative activity.

The emergence of non-institutionalised forms of participation has often been interpreted as evidence of the deterioration of public engagement as a

${ }^{5}$ Tarrow. Power in movement: Social movements and contentious politics. The research about the influence of Political Opportunity Structures on organizations has showed how we could explain some differences among organizations due to external conditions. The work of Morales about this issue shows a general overview of these differences among associations across Europe, Joining political organizations: institutions, mobilisation and participation in western democracies. 
result of the individualistic spirit they were associated with (Crozier et al. 1975; Putnam 1996). However, according to our results, the attitudes that are normally associated with the civic spiral of participation seem to respond better to non-institutionalised forms of political engagement. It must be borne in mind that even in France and Spain, where the forms of participation are complementary, the variables that help explain institutional participation have no influence on the variables that help explain non-institutional participation and vice-versa. Therefore they do not seem to be simply two different ways of exercising political influence, but rather two different ways of understanding political engagement.

The thesis regarding the normalisation of protest in contemporary societies has significantly broadened the vision of these new forms of political engagement (Aelst and Walgrave 2001). Nevertheless, our study suggests that in Germany and Norway non-institutional forms of participation are still political expressions with a strong identity-related content. Something similar happens in France, although the further South we go, both forms of participation, also in France, are complementary for citizens, which means that both models of participation become in turn a repertoire of possibilities of action for all citizens.

Much has been written about the advantages of associational activity in the public life of any community (Putnam 1993; Deth 2001; Hirst 2002; Kwak et al. 2004). A priori this is not a point we can deny, considering the complementariness of both forms of participation in Spain and France. However, it does seem possible to contextualise the role attributed to associations in the light of the results of our study, which can help us clarify the phenomenon of participation, as well as valuing public efforts to increase democratisation through measures strongly tending to support associationalism. It is true that, associational activity has been an indicator of engagement in the life of a community and has often been understood as an indicator of citizen commitment to democratic values (Putnam 2000; Warren 2001; Deth 2001). However, we believe that democratic values cannot be explained only by reference to the associational world, which may even show ambiguous attitudes in this regard, when we consider a broad attitudinal context (exogenous variables) and its interrelation with non-institutional forms of participation.

The main problem is related with the importance attributed to associational activities as an explanatory variable of participation in general and, by extension, as a reflection of the democratic political context (Putnam 2000; Warren 2001). The model proposed shows that associational activity cannot explain the participation phenomenon as a whole and, therefore, participation is not globally subsumed in the associational world. If social trust is important from 
the point of view of democracy and the way it works, it would seem reasonable to think about forms of democracy linked to a less institutionalised participation. In this regard we could question the equation which has often linked democratic health with associational vigour, as pointed out by Delhey and Newton (2002), inverting this relationship. If we consider social trust, sociability or conversation about politics, we can consider that the civic values of democracy (the ability to put oneself in others' shoes, to dialogue and to argue, as well as to participate with other different people) find more support in non-institutionalised individual participation. This hypothesis is not new; in a study on social trust in the US, the authors came to the conclusion that the most one could expect from associations was a particularised trust, generating values that are very different from those normally associated with a civic democratic culture -strong and exclusive links within the association; weak links and distrust towards the outside- (Uslaner and Conley 2003).

Our study shows an evolution in non-institutional forms of participation over time that is difficult to ignore. We have gone from considering them to be expressions bordering illegality (Crozier et al. 1975) to taking them as normalised tools for citizens (Aelst and Walgrave 2001). We can now start to consider them from the point of view of the implications they have for an individual interested in exercising political influence. In some ways our study helps us see that for individuals the two forms of participation may be two different forms of political engagement.

Questioning the social spiral deriving from participation has flared up the debate regarding the place it occupies in contemporary societies. It has also had a direct consequence on the deliberative shift in political theory, by questioning it. As Mutz (2006) says, the qualities of deliberation rest on trust, the ability to listen and accept differences, elements that were traditionally associated with the world of participation. When these attitudes are not found, especially among the people who tend to participate, the grounds for deliberation as a political procedure disappear. This questioning has reached the very meaning of participation, it being understood that if those who participate do not have the civic values expected of them, a policy based on citizen engagement and dialogue with citizens could also lose grounds for justification (Hibbing and Theiss-Morse 2002).

It does not seem possible to deny the evidence that many studies have pointed to regarding the political attitudes associated with institutionalised participation. But we can question openly the fact that the whole participation phenomenon is equated with that type of participation. There are many citizens who do not participate in associations but that does not mean they do not par- 
ticipate, and when they do, they do not always have the same attitudinal motivations as those linked to the associational world. Perhaps for this reason it would be interesting to think of other forms of institutional political engagement not directly dependent on associational activity. If Mutz finds that individuals who do not participate in associations are more inclined to accept a deliberative context, it might be positive to offer new mechanisms of participation that allow these individuals to engage politically without having to become a member of an organisation.

Today there are many participation procedures that embrace a type of political engagement that is closer to non-institutional forms of participation than institutional forms (Smith 2009. Participatory budgeting, citizen juries, deliberative pools are examples of this. They are all based on individual participation, they all introduce deliberative procedures and none of them require participants to become a member of any association. It is illustrative that Spain is the European country where participatory budgeting has been most developed, whereas in Northern Europe the experiences of this are still marginal (Sintomer, Herberzg and Röcke 2008). The differences we have pointed out show that through these forms of institutional participation it would be possible to favour a political engagement closer to the civic spirit associated with democracy.

If we accept the hypothesis that associations are not 'democracy schools' as Meer and Ingen pointed out (Meer and Ingen 2009), the results of our study cannot be deemed odd either, in that they suggest that it is those individuals who already have those values who are most inclined to participate in non-institutional channels. This could also be explained on the basis of structural changes in contemporary societies, which would have favoured the development of a more horizontal socialisation, based on the autonomy of individuals, where these can hold open discussions about the goals of institutional politics and set themselves apart with regard to their achievements and institutional direction (Offe 2006).

Research on the organisation of associations points to a tendency of these associations to adopt hierarchical organisations and structures lacking a connection with their environment (Maloney and Robteutscher 2007). It might be suggested that the associative structure and the role played in it by the individual is not significant from the point of view of the individual's civic attitudes (Meer and Ingen 2009). However, it is illustrative to point out that individuals who tend to participate in non-institutional ways, as has been shown in this study, tend to talk of politics regularly and to be open to their environment (social trust, sociability), as opposed to associated individuals. 
Unlike participation through associations, protest forms offer a range of far less expensive possibilities of political engagement. This has surely been a factor behind their normalisation, which has also meant that it is no longer necessary to be a member of an organisation to have influence or to be active politically. To do it through these means also guarantees autonomy and control as regards the degree of support, but also a feeling of engaging in a specific action whose results depend on others, which makes it necessary to become part of a deliberative medium.

In short, our study shows that institutionalised participation is not only a different way of participating, but also a different form of political engagement for citizens, which can have a significant impact on the way of understanding politics and democracy in contemporary societies. From this point of view, the question regarding participation we posed at the start of this paper brings about a range of new possibilities of political engagement of citizens in political issues. Perhaps the problem of disinterest is a result of an institutional politics that is too much geared towards associations. What would happen if the administration opened up to forms of participation closer to the spirit of noninstitutional forms of participation? This question opens up another discussion and points to the need for further research regarding political engagement in contemporary societies based on different forms of participation.

\section{REFERENCES}

Aelst, Peter van and Stefaan Walgrave, S. (2001). "Who is that (wo)man in the street. From the normalization of protest to normalization of protester." European Journal of Political Research 39: 461-486

Arzheimer, Kai and Elisabeth Carter. (2006). "Political opportunity structures and rightwing extremist party success." European Journal of Political Research 45: 419-443.

Barnes, Samuel H and Max Kaase (eds). (1979). Political Action. Mass Participation in Five Western Countries. Beverly Hills, CA: Sage.

Bryan, Frank. (2004). Real Democracy: The New England Town Meeting and How It Works. Chicago: University Chicago Press.

Chandler, Jim A. (2000). Comparative Public Administration. New York: Routledge

Cohen, Jean L. and Andrew Arato. (1992). Civil Society and Political Theory. Cambridge: MIT Press

Council of Europe Committee of Ministers. (2001). Recommendation Rec (2001) 19: "Participation of citizens in local public life" (www.coe.int)

Crozier, Michel, Samuel P.Huntington and Joji Watanuki. (1975). The crisis of democracy. New York: New York University Press.

Dalton, Russell J. (1999). "Political support in advanced industrial democracies" in Critical citizens: global support for democratic governance, edited by Pippa Norris. Oxford: Oxford University Press. 
Delhey, Jan and Kenneth Newton. (2002). Who trusts? The origin of social trust in seven nations. Berlin: WZB Publications.

Deth, Jan van. (2001). "The Proof of the pudding: social capital, democracy and citizenship". Paper prepared for EURESCO Conference on "Social capital: Interdisciplinary perspectives". Exeter, UK, 15-20 September 2001.

Deth, Jan van. (2006). "Democracy and involvement: the benevolent aspects of social participation" in Political Disaffection in Contemporary Democracies: Social Capital, Institutions and Politics, edited by Torcal y Montero, 101-129. London: Routledge.

Deth, Jan van y Elff, M. (2004). "Politicisation, economic development and political interest in Europe". European Journal of Political Research 43: 477-508.

Eliasoph, Nina. (2001). Avoiding Politics: How Americans Produce Apathy in Everyday Life. Cambridge: CUP

Gamson, William. (1990). The strategy of social protest. California: Wadsworth.

Habermas, Jurgen. (1996). Between Facts and Norms: Contributions to a Discourse Theory of Law and Democracy. Cambridge: MIT Press.

Hibbing, John R. and Elisabeth Theiss-Morse. (2002). Stealth Democracy. Cambridge: CUP

Hirst, Paul. (2002). "Renewing Democracy through Associations". Political Quartely 73(4): 409-422.

Jordan, Grant and William Maloney. (1997). The Protest Business? Mobilizing Campaign Groups. London: Paperback.

Jöreskog, Karl G. and Dag Sörbom (1989). Lisrel 7: A guide to the program and applications. Chicago: SPSS.

Kitschelt, Herbert. (1986). "Political opportunity structures and political protest: Antinuclear movements in four democracies". British Journal of Political Science 16: 57-85

Kline, Rex B. (1998). Principles and Practice of Structural Equation Modeling. New York: Guilford Press.

Kwak, Nojin, Dhavan V. Shah. and R. Lance Holbert. (2004). "Connecting, trusting and participating: the direct and interactive effects of social associations". Political Research Quartely 57 (4): 643-652.

Kwon, Hyeong-ki. (2004). "Associations, civic norms and democracy: revisiting the italian case". Theory and Society 33: 135-166.

Lichterman, Paul R. (2006). "Social capital or group style? Rescuing Tocqueville"s insights on civic engagement". Theory and Society 35: 529-563.

Maloney, William and Sigrid RoBteutscher, eds. (2007). Social capital and associations in European democracies: a comparative analysis. London: Routledge

Meer, TOM van der and Erik van Ingen. (2009). "Schools of Democracy? Disentangling the relationship between civic participation and political action in 17 European countries". European Journal of Political Research 48: 281-308

Micheletti, Michel, Andreas Follesdal and Dietlind Stolle. (2004). Politics, products and markets. Exploring political consumerism past and present. New Jersey: Transaction Publishers. 
Morales, Laura. (2009). Joining political organizations: institutions, mobilisation and participation in western democracies. Colchester: ECPR Press

Mutz, Diana. (2006). Hearing the other side: deliberative versus participatory democracy. New York: CUP.

Newton, Kenneth. (2006). "Institutional confidence and social trust: aggregate and individual relations" in Political Disaffection in Contemporary Democracies: Social Capital, Institutions and Politics, edited by Torcal y Montero, 81-100. London: Routledge.

Newton, Kenneth and Pippa Norris (2000). "Confidence in public institutions: faith, culture or performance" in Disaffected democracies: what"s troubling the trilateral countries, edited by Pharr, S.J. and Putnam, R.D. Pricenton: Pricenton University Press.

Norris, Pippa. (1999). "Conclusions: the growth of critical citizens and its consequences" in Critical citizens: global support for democratic governance, edited by Pippa Norris. Oxford: Oxford University Press.

Norris, Pippa. (2001). "Making democracies work: social capital and civic engagement in 47 societies". Paper prepared for EURESCO Conference "Social capital: interdisciplinary perspectives". Exeter, UK, 15-20 September 2001.

Norris, Pippa; Stefaan Walgrave and Peter van Aelst. (2006). "Does protest signify disaffection? Demonstrators in a postindustrial democracy" in Political Disaffection in Contemporary Democracies: Social Capital, Institutions and Politics, edited by Torcal y Montero, 279-307. London: Routledge.

OECD. (2001). Citizens as partners. Information, consultation and public participation in policy-making. Paris: OCDE.

Offe, Claus. (1985). "New Social Movements: Challenging the Boundaries of Institutional Politics". Social Research 52(4): 817-867

Offe, Claus. (2006). "Political disaffection as an outcome of institucional practices? Some post-Tocquevillian speculations" in Political Disaffection in Contemporary Democracies: Social Capital, Institutions and Politics, edited by Torcal y Montero, 23-45. London: Routledge.

Porta, della Donatella and Mario Diani. (1999). Social movements: an introduction. Oxford: Blackwell.

Putnam, Robert. (1993). Making democracy works. Princeton: Princeton University Press.

Putnam, Robert. (1996). "The strange disappearance of civic America", American Prospect 24: 34-48.

Putnam, Robert. (2000). Bowling Alone: The Collapse and Revival of American Community. NewYork: Simon and Schuster.

Schlozman, Kay Lehman; Sidney Verba and Henry E. Brady. (1995). "Participation"s not a paradox: the view from American activists". British Journal of Political Science 25: $1-36$.

Sintomer, Yves; Carsten Herberzg and Anja Röcke. (2008). Démocratie participative et modernisation des services publics. Paris: La Découverte. 
Smith, Graham. (2009). Democratic Innovations: designing institutions for citizen participation. Cambridge: CUP.

Tarrow, Sidney. (1998). Power in movement: Social movements and contentious politics. Cambridge: CUP.

Theiss-Morse, Elisabeth and Hibbing, John R. (2005). "Citizenship and civic engagement". Annual Review of Political Sciences 8: 227-49

Torcal, Mariano and Ignacio Lago. (2006). "Political participation, information and accountability: some consequences of political disaffection in new democracies" in Political Disaffection in Contemporary Democracies: Social Capital, Institutions and Politics, edited by Torcal y Montero, 308-331. London: Routledge.

Torcal, Mariano and Juan Ramón Montero, eds. (2006). Political Disaffection in Contemporary Democracies: Social Capital, Institutions and Politics. London: Routledge.

Uslaner, Eric. (2004). "Bowling almost alone: political participation in a new democracy". ECPR Joint Sessions of Workshops, Emerging Repertories of Political Action: Toward a Systematic Study of Postconventional Forms of Participation, Uppsala, Sweden, April 13-18.

Uslaner, Eric and Richard Conley. (2003). "Civic engagement and particularized trust". American Political Research. 31(10): 1-31.

Uslaner, Eric and Paul Dekker. (2001). "The "social" in social capital" in Social capital and participation in everyday life, edited by P. Dekker and E. Uslaner. London: Routledge.

Warren, Mark. (2001). Democracy and association. Princeton: Princeton University Press.

Wollebaek, Dag and Per Selle. (2002). "Does participation in voluntary associations contribute to social capital? The impact of intensity, scope and type". Nonprofit and Voluntary Sector Quarterly 31(1): 32-61.

Wollmann, Hellmut, ed. (2003). Evaluation in Public Sector Reform: concepts and practice in international perspective. Cheltenham: Edward Elgar Publishing

ERNESTO GANUZA FERNÁNDEZ es Científico Titular en el Instituto de Estudios Sociales Avanzados (del Consejo Superior de Investigaciones Científicas). Trabaja sobre temas relacionados a la Democracia, Sociedad Civil o los conflictos que surgen con los espacios políticos contemporáneos abiertos a la participación y la deliberación. Ha trabajado como consultor de diversos municipios en España en temas de participación, además de participar en varias investigaciones internacionales sobre participación política. Ha publicado diversos artículos y libros sobre estos problemas, recientemente "El círculo virtuoso de la democracia" (junto a Francisco Francés) y próximamente publicará "Democracy in Motion" (junto a Gianpaolo Baiocchi). 
FRANCISCO JOSÉ FRANCÉS GARCÍA es premio extraordinario de doctorado en Sociología por la Universidad de Alicante, donde es profesor en el Departamento de Sociología II. Sus principales líneas de investigación se centran en la participación social, sociología política, migraciones, y juventud. Ha colaborado como investigador distintas instituciones nacionales e internacionales, y participado en más de una veintena de proyectos públicos. En materia de participación y es coautor de diversos libros y artículos en revistas internacionales y ha coordinado distintos procesos comunitarios vinculados a este ámbito.

Recibido: $14 / 04 / 2015$

Aceptado: 26/06/2015 